\title{
Oncogenes and onco-suppressor gene in adenocarcinoma of the oesophagus
}

\author{
J Jankowski, G Coghill, D Hopwood, K G Wormsley
}

\begin{abstract}
While the activation of the proto-oncogenes has been implicated in the development and progression of cancer of many tissues, the role of oncogenes in the development of oesophageal adenocarcinoma has not been defined. Fifteen patients who had undergone resection for oesophageal adenocarcinoma and 15 who had undergone oesophagectomy or biopsy for Barrett's oesophagus were studied. The latter patients also had adjacent normal gastric mucosa biopsied for comparison with the metaplastic oesophageal mucosa. The mucosal samples were snap frozen and subsequently stained with monoclonal antibodies to the following oncogene associated proteins; c-erbB2 (neu and CE-1) (external domain), cerbB2 (NCL-CB11) (internal domain), c-src, c-ras, c-myc, c-fos, c-jun, and the oncosuppressor gene $-\mathrm{p} 53$. All tumours were well or moderately differentiated adenocarcinomas arising from the lower third of the oesophagus. Eleven specimens showed strong membraneous staining with both c-erbB2 (neu) and c-erbB2 (CBL-CB11). Seven specimens showed strong nuclear staining with p53 oncosuppressor gene. Three specimens were positive for c-ras and c-src, and two were positive for c-jun. In Barrett's epithelium, nine specimens were positive for c-erbB2 (neu and CB11), three were positive for c-src, two were positive for c-ras and c-jun, and one was positive for c-fos. Two of the gastric mucosal biopsy specimens expressed c-erbB 2 weakly but no other oncogenes were found. The frequency of positive staining for c-erbB2 is very high, compared with the expression of these genes in other tumours. It is also concluded that errors in the onco-suppressor gene p53, and especially in the external and internal domains of c-erbB2, which is also often expressed in Barrett's mucosa, may be implicated in the development of adenocarcinoma of the oesophagus.
\end{abstract}

(Gut 1992; 33: 1033-1038)

Departments of Medicine and Pathology, University of Dundee

J Jankowski

G Coghill

D Hopwood

K G Wormsley

Histopathology Unit, Imperial Cancer Research Fund, London J Jankowski

Correspondence to: Dr J Jankowski, Histopathology Unit, Imperial Cancer Research Fund, 35-43 Lincoln's Inn Fields, London WC2A 3PN.

Accepted for publication 6 December 1991

In the past decade considerable progress has been made in the identification of genes that encode proteins controlling the complex cascade of processes regulating the proliferation and differentiation of cells. ${ }^{1-3}$ The proliferation of normal and malignant cells is regulated by both inhibitory and stimulatory control molecules, derived from tumour suppressor genes and proto-oncogenes respectively. $^{+6} \mathrm{~A}$ tendency towards cancer-associated loss of normal growth control can result from loss or inactivation of both copies of a tumour suppressor gene or from mutation, with amplification of hyperactivation of one or both of the two copies of one, or more, proto-oncogenes. ${ }^{7-10}$

In addition, recent reports have suggested that the degree and type of oncogene expression in some tumours (breast, ovary, pancreatic, stomach, and colon) may have prognostic importance. ${ }^{11-15}$

Oncogenes can be divided into three categories according to their subcellular localisation and their function in cellular transformation growth factor oncogenes; signal transducer genes; and oncogenes encoding nuclear proteins. ${ }^{48} \mathrm{We}$, and others, have previously reported abnormal expression of growth factors and their receptors in oesophageal adenocarcinomas. ${ }^{1617}$ It therefore seemed pertinent to assess also the expression of membrane associated signal transducer genes and 'nuclear oncogenes', particularly since abnormal expression of these oncogenes may be implicated in the development of Barrett's oesophagus (a precurser of adenocarcinoma) as well as adenocarcinomas.

\section{Patients and methods}

Fifteen patients who had undergone oesophageal resection for oesophageal adenocarcinoma (mean age 67 years, range 51-76) were assessed in addition to 15 others who had undergone biopsy or resection for Barrett's oesophagus (mean age 64 years, range $43-80$ ).

Forty five specimens were evaluated, comprising 15 resected adenocarcinomas, 15 cases of Barrett's oesophagus, and paired biopsy specimens of normal gastric mucosa from the latter 15 patients.

Specimens were snap frozen and subsequently cut to $6 \mu \mathrm{m}$ sections. Routine histological assessment was performed using haematoxylin and eosin stained sections. The degree of differentiation of the cancers was classified according to previous criteria. ${ }^{18}$ The lesions of Barrett's oesophagus were graded for metaplasia and dysplasia according to the criteria of Whitehead ${ }^{19}$ and Riddell ${ }^{20}$ respectively.

The following monoclonal antibodies were used to assess expression of appropriate genes: internal domain of c-erbB2, NCL-CB11 (IgG, Novocastra; ${ }^{21}$ external domain of c-erbB2 neu TAl (IgG, Du Pont); ${ }^{22}$ anti-pan ras p21 (IgG, Du Pont) ${ }^{23}$ anti-p53 (IgG, gift from Professor D Lane, Biochemistry Dept, Dundee); $;^{2+}$ c-src (IgG, Cambridge Research Biochemicals); ${ }^{25} \mathrm{c}$ jun (IgG, Cambridge Research Biochemicals Ltd); c-fos (IgM Bionuclear Services Ltd); and c-myc (IgG, Cambridge Research Biochemicals).

Sections were fixed in acetone for five minutes at room temperature, and then stained according to the indirect immunoperoxidase technique with biotinylated mouse IgG (DAKO) as a 
TABLE I Staining patterns of monoclonal antibodies to oncogene and anti-oncogene associated epitopes

\begin{tabular}{|c|c|c|c|}
\hline Oncogene & Dilution & Tissue stained & Staining pattern \\
\hline NEU & $1 / 10$ & Epithelium & Membranous and \\
\hline CB11 & $1 / 5$ & Epithelium & $\begin{array}{l}\text { Membranous and } \\
\text { cytoplasmic }\end{array}$ \\
\hline c-src & $1 / 100$ & Epithelium & $\begin{array}{l}\text { Cytoplasmic and } \\
\text { membranous }\end{array}$ \\
\hline c-ras & $1 / 20$ & Epithelium & Cytoplasmic \\
\hline$c$-jun & $1 / 50$ & Epithelium & Cytoplasmic and nuclear \\
\hline c-fos & $1 / 10$ & $\begin{array}{l}\text { Epithelium and } \\
\text { stromal cells }\end{array}$ & Nuclear \\
\hline $\mathrm{p} 53$ & $1 / 10$ & Epithelium & $\begin{array}{l}\text { Cytoplasmic and } \\
\text { membranous }\end{array}$ \\
\hline
\end{tabular}

secondary antibody followed by streptavidine, and this product was visualised by diamine benzadine as described previously. ${ }^{26}$

Positive control sections included lymph node containing lymphoma (c-myc, c-jun, and c-fos demonstrated staining confined to the nucleus of lymphocytes and stromal cells), mammary and gastric adenocarcinomas (c-erbB2 internal and external domains and c-src demonstrated strong membranous staining in epithelial tissues) (c-ras demonstrated moderate cytoplasmic staining in epithelial tissues), colonic adenocarcinomas (p53 demonstrated strong nuclear staining in epithelial cells).

Negative control sections for each oncogene were processed immunohistochemically without the primary antibody.

Immunohistochemical staining of cell membranes (C-erbB2, C-src), cytoplasm (c-ras), or nucleus (c-myc, c-fos, c-jun and p53) was scored by assessing both the intensity of staining and the proportion of cells stained, based on a modification of the technique of Corbett et al. ${ }^{21}$ Cytoplasmic staining was not considered to be positive for the purposes of semi-quantitation of c-erbB2. When cytoplasmic c-erbB2 staining was present it was noted separately (Table I).

Briefly, intensity was scored on a four point scale: no staining $=0$; weak staining $=+$; moderate staining $=++$; and intense staining $=$ +++ . The proportion of cells staining was also scored on a four point scale: no cells staining $=0$; $1-39 \%$ staining $=\mathrm{I} ; 40-69 \%$ staining $=\mathrm{II} ; 70-$ $100 \%$ staining $=$ III

Two individuals assessed each section and there was complete agreement in $95 \%$ of cases with regard to the intensity and pattern of staining. In the few sections in which scores differed, the two observers agreed a common score.

TABLE II Percentage of positive expression of oncogene and anti-oncogene associated antigens in the oesophagus in health and disease

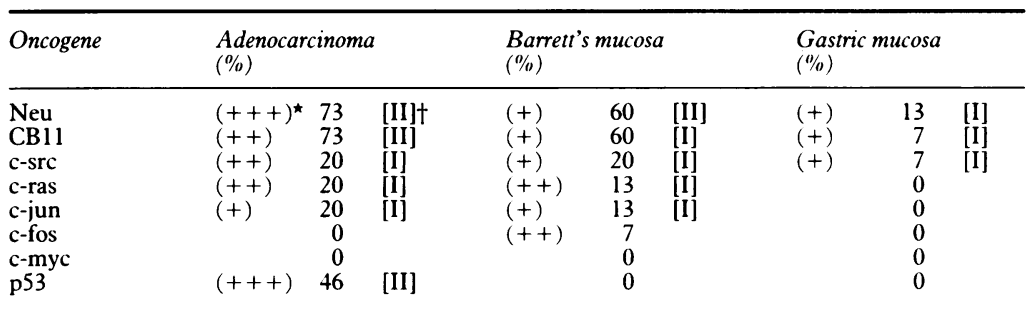

*Average staining intensity in positive sections in brackets; $(+)=$ weak, $(++)=$ moderate,

$(+++)=$ intense

Average staining intensity in positive sections in square brackets; $[\mathrm{I}]=1-39 \%,[\mathrm{II}]=40-69 \%$, [III $]=70-100 \%$

\section{Results}

All adenocarcinomas were well or moderately differentiated. Of the 15 cases of Barrett's oesophagus, eight contained mainly $(>90 \%$ mucosa) intestinal type mucosa, three contained mainly (>90\%) gastric type mucosa, and four contained both types of epithelium. All gastric mucosal biopsy specimens were histologically unremarkable.

The pattern of positive expression of different oncogenes was variable. For example, c-erbB2 (neu and CB11) showed both membranous distribution and minimal cytoplasmic staining in most positive cells. C-erbB2 cytoplasmic staining was not included in the assessment of staining density; this included only membranous staining as suggested previously. ${ }^{21} \mathrm{C}$-src showed predominantly cytoplasmic distribution with minimal membranous staining. Similarly, c-ras and c-jun had a cytoplasmic pattern of reactivity whereas c-fos and p53 were both nuclear (Table I). C-myc failed to react positively with any of the sections under study, although a control section of lymph node containing lymphoma showed positive staining (Table II).

The density of staining for all oncogenes was variable throughout the sections (Table II). The staining pattern also varied from one cancer to another and one section of Barrett's oesophagus to another.

The proportion of cells positively stained also varied from one section to another, but to a lesser degree.

\section{BACKGROUND STAINING}

Background staining was minimal or absent in most sections and did not therefore interfere with semiquantitation. The following antibodies achieved particularly specific staining with an absence of background staining; neu, CB11, p53, c-ras, and c-fos. The following antibodies had some diffuse background staining usually localised in superficial epithelial cells or stromal tissue; c-jun, c-myc, and c-src. With empirical methods of dilution and application of fetal calf serum $(1 / 25)$, before incubation with the primary antibodies we were able to minimise the background staining.

\section{MEMBRANE BOUND ONCOGENES}

Both the internal and external domain of c-erbB2 (Fig 1) were coherently expressed in most sections from oesophageal carcinomas and Barrett's oesophagus $(73 \%$ and $60 \%$, respectively). Seven sections with Barrett's intestinal type mucosa stained positively. In addition to the membranous staining, there was mild-moderate cytoplasmic staining in 6 of 12 sections of positively staining carcinomas and 5 of 9 sections of Barrett's oesophagus (one with mild dysplasia). There was no cytoplasmic staining in normal mucosa. In two sections, however, weak membranous staining was present in superficial and foveolar type cells of the gastric crypts. 

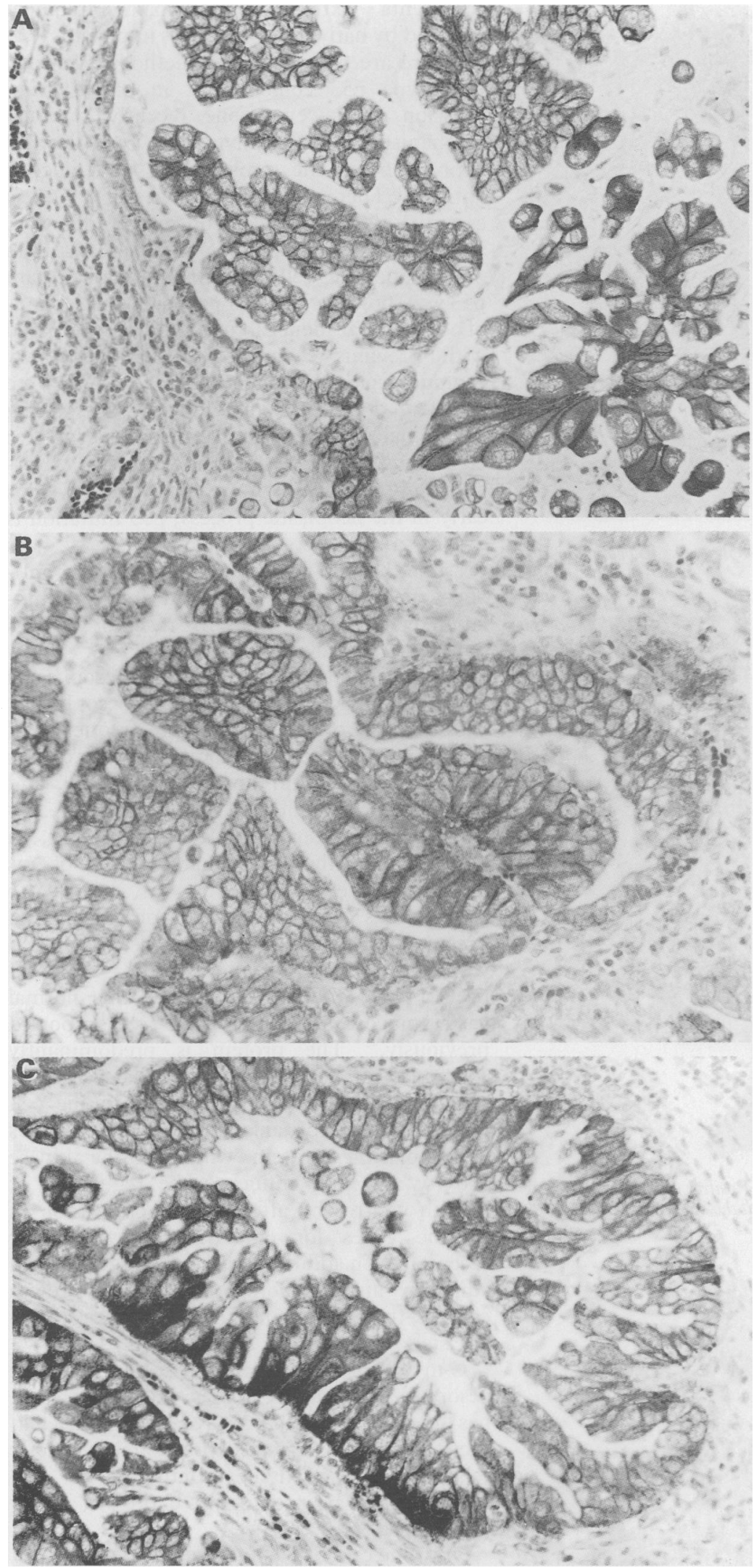

Figure 1: (A)C-erbB2 neu (external domain) in adenocarcinoma of the oesophagus (original magnification $\times 450)$. (B) C-erbB2 CB-11 (internal domain) in adenocarcinoma of the oesophagus (original magnification $\times 450)$. (C) C-erbB2 neu in Barrett's gastric type mucosa (original magnification $\times 450$ ). healthy gastric mucosa also expressed c-src weakly in the cytoplasm of epithelial cells.

\section{NUCLEAR ONCOGENES}

C-myc was not demonstrated in any oesophageal sections. C-fos (Fig 4) was found in one case of Barrett's oesophagus (gastric type metaplasia). C-jun (Fig 5) was found in $20 \%$ of oesophageal cancers and in $13 \%$ of Barrett's oesophagus. The pattern of expression was mainly cytoplasmic rather than nuclear.

\section{P53 ANTI-ONCOGENE}

Seven of 15 (Fig 6) oesophageal adenocarcinomas stained strongly positive in the nuclei with $\mathrm{p} 53$ antiserum. All staining was confined to the malignant mucosa with no staining of the stromal nuclei. In the sections that stained positively, approximately $40-70 \%$ of malignant cells were stained with $\mathrm{p} 53$. One section of non-dysplastic Barrett's mucosa had occasional faint nuclear staining.

\section{Discussion}

The results of the present study show that cerbB2 internal and external domains are coherently expressed in oesophageal adenocarcinomas and Barrett's oesophagus. The coherent expression of internal and external domains of c-erbB2 has also been reported in mammary carcinoma. ${ }^{11}$ The erbB2 protein on cell membranes has a strong correlation with its corresponding mRNA which, in turn, is produced by amplification of the erbB2 protooncogene..$^{212}$

The present study has shown a very high incidence of membranous erbB2 expression in both malignant and Barrett's oesophageal tissue (73\% expression and $60 \%$, respectively) compared with the lower frequency of expression in other gastrointestinal cancers (gastric 30\% and colonic $50 \%)^{131727-30}$ This finding is interesting because we have recently reported an increased expression of epidermal growth factor receptors (EGF-R), which also have tyrosine kinase activity, in both oesophageal cancer and Barrett's epithelium. ${ }^{16}$ However, the $\mathrm{COOH}$ domain of EGF-R and c-erbB2 exert different transforming activity, ${ }^{31}$ The erbB2 $\mathrm{COOH}$ domain has a positive stimulatory effect on erbB2 oncogenic activity, perhaps accounting for the fact that tumours expressing erbB2 have both a poorer short term $(<5$ years) as well as long term $(>10$ years) prognosis. ${ }^{1612162830}$ Moreover, tumours with erbB2 expression have been reported to metastasise readily. ${ }^{616}$ In this context, we have shown a paucity of c-erbB2 expression in epithelial membranes in normal gastric mucosa, with greater levels found in Barrett's oesophagus and the greatest levels of c-erbB2 expression on oesophageal carcinomas. In this respect membranous c-erbB2 expression is a marker for malignant potential, however, it has been suggested that cytoplasmic c-erbB2 expression, noted also in six sections of adenocarcinoma, may have less prognostic importance than membranous expression."1 Whether this staining carcinomas and $14 \%$ of Barrett's oesophagus (both of the latter had intestinal metaplasia). Csrc (Fig 3) was expressed in $20 \%$ of oesophageal carcinomas and also of Barrett's oesophagus ( 2 of 3 patients had intestinal metaplasia). One case of 


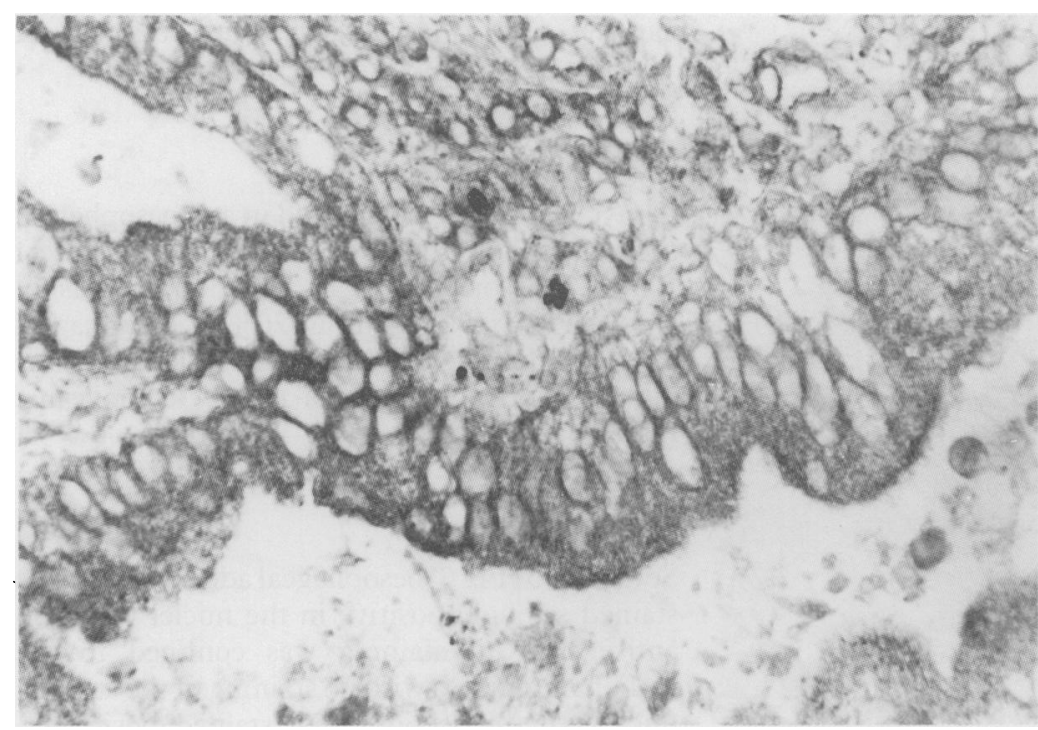

Figure 2: Expression of $c$-ras oncogene in the cell cytoplasm of oesophageal adenocarcinoma (original magnification $\times 700$ ).

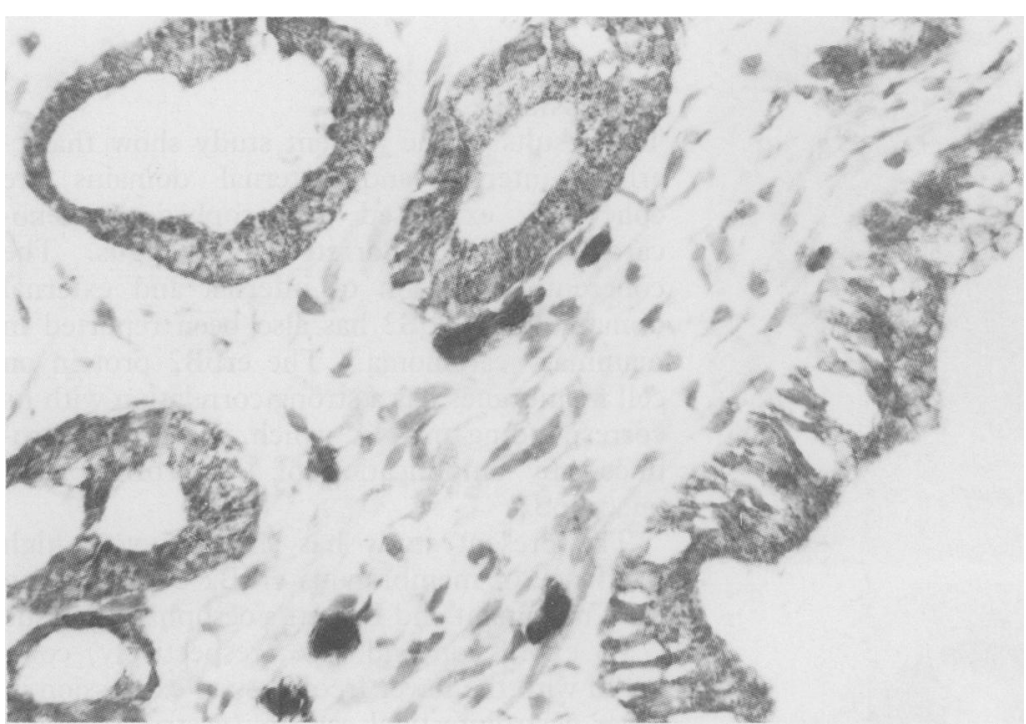

Figure 3: Expression of c-src in Barrett's intestinal type mucosa. (Positive cytoplasmic staining visible around goblet cells. Weak membranous staining is visible at the apical edge of the superficial epithelial membranes (original magnification $\times 700$ ).

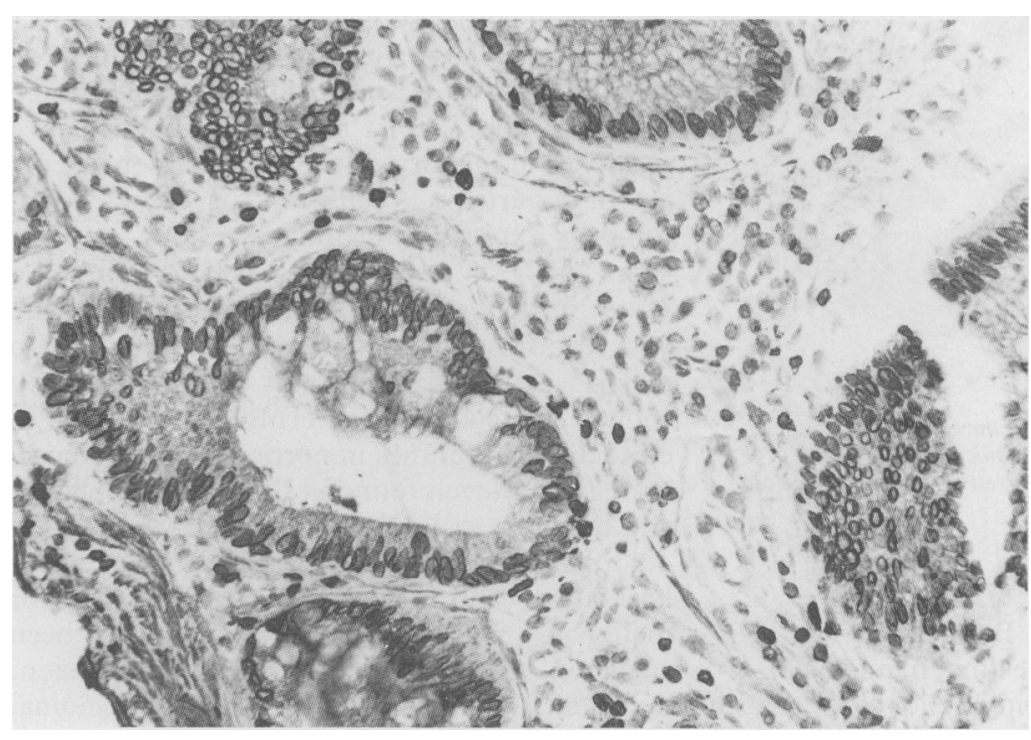

Figure 4: Expression of c-fos in Barrett's gastric type mucosa (original magnification $\times 200$ ). represents extracellular domain fragment secreted by native c-erbB gene is uncertain. ${ }^{3}$

There are many possible methods by which wild type p53 could result in growth suppression, 3233 however, one recently reported mechanism is by selective down regulation of expression of the proliferating cell nuclear antigen..$^{33}$ Therefore wild type $\mathrm{p} 53$ seems to exert essential inhibitory effects on cell proliferation, and therefore mutation of p53 may result in deregulation of cellular proliferation. Mutant p53 was shown in a similar proportion of sections of oesophageal adenocarcinoma (46\%) compared with previous reports of other alimentary tumours (colonic carcinoma 33\%). ${ }^{1+3435} \mathrm{We}$ were unable to demonstrate unequivocal p53 staining in (premalignant) Barrett's mucosa, irrespective of the presence or absence of dysplasia. ${ }^{14}$ However, unlike erbB2, expression of which develops early in the neoplastic process, p53 mutation is usually a late step in carcinogenesis. ${ }^{101+}$ It is possible that the failure of this regulatory 'antioncogene' results in unopposed growth stimulation by the EGF-R and erbB2 receptor which is 'normally limited' in the nucleus by $\mathrm{p} 53 .{ }^{36}$

We found c-ras in $20 \%$ of oesophageal carcinomas and $14 \%$ of Barrett's oesophagus. These values are lower than the frequency of expression in other carcinomas (colonic cancer $25 \%$, pancreatic and breast cancer $30 \%$, and gastric cancer $35 \%) .^{37-42}$ The relatively low frequency in oesophageal carcinoma may, in part, explain the undetectable levels of ras mRNA reported previously. ${ }^{38}$

C-src was expressed in $20 \%$ of oesophageal cancers and Barrett's oesophagus, compared with $30 \%$ of gastric adenocarcinomas reported previously. ${ }^{+3}$ We have also shown that normal gastric mucosa may also express c-src, as reported previously. ${ }^{+4}$ The protein is predominantly expressed in the Barrett's epithelial cell cytoplasm but also to a lesser extent in the cell membranes. $\mathrm{C}$-src is an oncogene which encodes a cytoplasmic protein with tyrosine kinase activity and may influence the regulation of growth control by affecting the expression of specific genes for epidermal growth factor receptors..$^{25}$ In addition c-src may deregulate cell adhesion and anchorage dependent growth control, thereby maintaining cells in a proliferative state. ${ }^{++3}$

C-myc was absent in all sections of the oesophageal adenocarcinomas. In this context it has been reported that c-myc has a short half life,${ }^{+5}$ furthermore c-myc expression is indirectly related to lack of tissue differentiation ${ }^{6 t h}$ and may not have been optimally expressed in our carcinomas.

Only one case of Barrett's gastric type mucosa was positive for $\mathrm{c}$-fos, perhaps because $\mathrm{c}$-fos is very unstable and has strong negative regulation."

C-jun was expressed most frequently of all the nuclear oncogenes. Unlike other nuclear genes, c-jun undergoes positive autoregulation. It has been reported that the degree of c-jun expression is involved in converting short term, proliferation inducing signals into long term memory, thus controlling the number of cell divisions. ${ }^{77}$ is The cytoplasmic expression of $\mathrm{c}$-jun in the present 


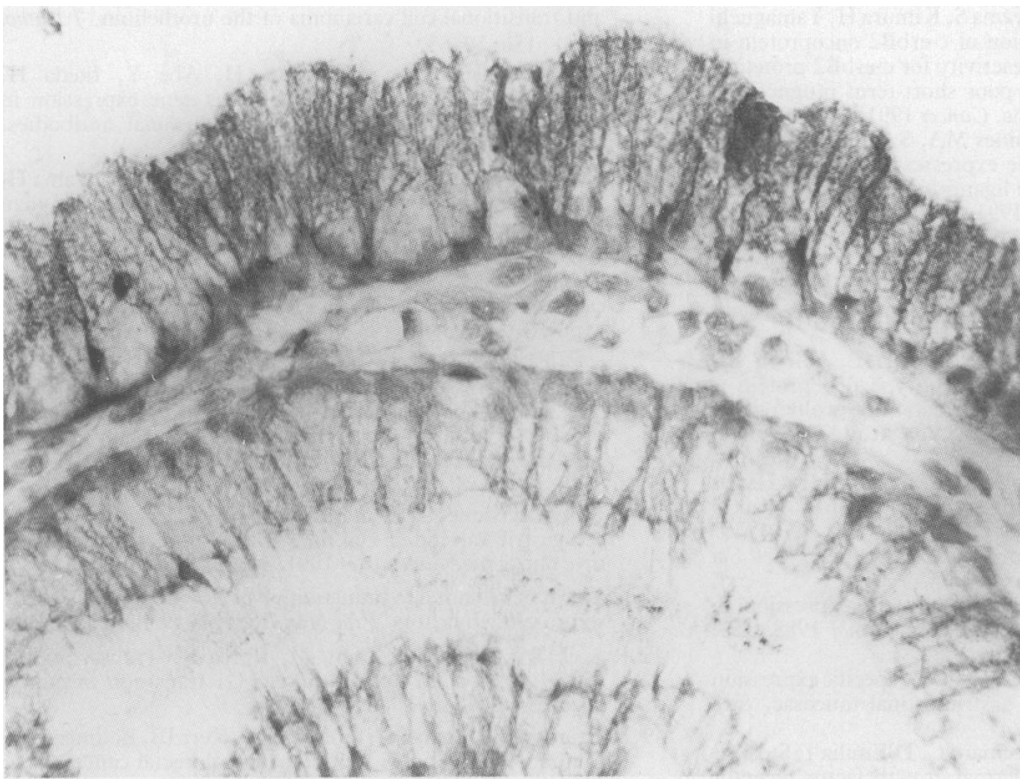

Figure 5: Expression of c-jun in Barrett's gastric type mucosa (weak staining of the apical cytoplasm is visible) (original magnification $\times 700$ ).

study may represent deregulation of the c-jun oncogene in oesophageal diseases as has been shown with other nuclear oncogenes like cmyc. ${ }^{45}$

It has been suggested that expression of one oncogene alone may not result in frank malignancy because cancers, as a rule, result from the chance occurrence in one cell of several independent genetic changes. ${ }^{+6}$ It is likely that the synchronous expression of oncogenes may act synergistically, gradually overcoming the negative feedback regulation of mitogenesis. In this respect, the expression of an abnormal p53 anti-oncogene, if it occurs at all, may represent a late step in the development of oesophageal cancer, although mutant p53 has occasionally been found in 'normal' epithelia. ${ }^{+950}$

In conclusion, we have shown that a variety of oncogenes are expressed in oesophageal adenocarcinoma and Barrett's oesophagus. The frequency of expression of c-erbB2 and p53

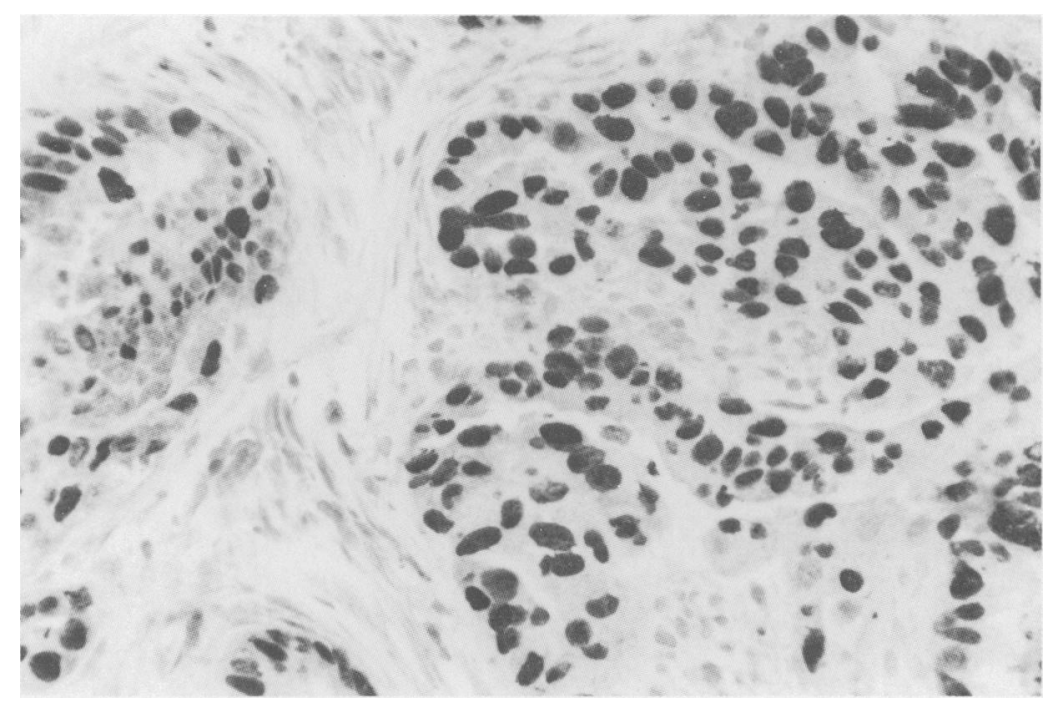

Figure 6: Expression of p53 oncogene in the nucleus of oesophageal adenocarcinoma (original magnification $\times 450$ ). suggests that the oncogene and an abnormal antioncogene may also be important in the development of oesophageal adenocarcinoma. ${ }^{19} \mathrm{We}$ are presently assessing the prognostic potential of these oncogenes, especially since the incidence of adenocarcinoma is inceasing in Tayside. ${ }^{51}$

1 Cell growth and division. In: Alberts B, Bray D, Lewis J, Raff M, Roberts K, Watson JD, eds. Molecular biology of the cell. New York: Garland Publishing, 1989: 727-90.

2 Benvenisty N. A molecular view of tissue differentiation and development. F R Coll Phys Lond 1989; 23: 156-60.

3 Hollywood D. Signal transduction. Br Med Bull 1991; 47: 99 115

4 Cancer. In: Alberts B, Bray D, Lewis J, Raff M, Roberts K, Watson JD, eds. Molecular biology of the cell. New York: Garland Publishing, 1989: 1187-217.

5 Lawley PD. Basic concepts of carcinogenesis. In: Cohen RD Lewis B, Alberti KGMM, Denman AM, eds. The metabolic and molecular basis of acquired disease. London: Bailliere and molecular basis

6 Graf T, Leutz A. Relationships between oncogenes and growth control. In: Sporn MB, Roberts AB, eds. Peptide growth factors and their receptors. Berlin; Springer-Verlag, $1990 ; 673-6$.

7 Spandidos DA, Anderson MLM. Oncogenes and oncosuppressor genes: their involvement in cancer. $\mathcal{f}$ Pathol 1989; 157: 1-10.

8 Sikora K. The molecules of cancer; the Watson Smith lecture 1990; F R Coll Phys Lond 1990; 24: 126-205.

9 Evans CW. The metastatic cell. London: Chapman and Hall, 1991: 100-310.

10 Sikora K. Cancer genes in gastrointestinal malignancy. Baillieres Clin Gastroenterology 1990; 4: 135-50.

11 Soomro S, Shousha S, Taylor P, Shepard HM, Feldman M $\mathrm{C}$-erbB2 expression in different histological types of invasive breast carcinoma. F Clin Pathol 1991; 44: $211-4$.

12 Hall PA, Hughes CM, Staddon SL, Richman PI, Gullick WJ, Lemoine NR. The c-erbB2 proto-oncogene in human pancreatic cancer. F Pathol 1990; 161: 195-200.

13 Falck VG, Gullick WJ. C-erbB2 oncogene product staining in gastric adenocarcinoma. An immunohistochemical study. $f$ Pathol 1989; 159: 107-11

14 Van den Berg FM, Tigges AJ, Schipper MEL, Den HartogJager FCA, Kroes WGM, Walboomers JMM. Expression of the nuclear oncogene p53 in colon tumours. F Pathol 1989; 157: 193-9.

15 Haldane JS, Hird V, Hughes CM, Gullick WJ. C-erbB2 oncogene expression in ovarian cancer. $\mathcal{F}$ Pathol 1990; 162: 231-7.

16 Jankowski J, McMenemin R, Penston J, Hopwood D, Wormsley KG. Abnormal expression of growth regulatory factors in Barrett's oesophagus. Clin Sci 1991; 81: 663-8.

17 Gullick WJ, Prevalence of aberrant expression of the epiderma growth factor receptor in human cancers. Br Med Bull 1991 47: 87-98.

18 Whitehead R. Adenocarcinoma. In: Whitehead R, ed. Gastrointestinal and oesophageal pathology. Edinburgh: Churchill-Livingstone, 1989: 702-24.

19 Hamilton SR. Adenocarcinoma in Barrett's oesophagus. In Whitehead R. ed. Gastrointestinal and oesophageal pathology. Edinburgh: Churchill-Livingstone, 1989;683-701.

20 Riddell RH, Goldman H, Ransohoff DF. Dysplasia in inflammatory bowel disease: standardised classification with provisional clinical applications. Hum Pathol 1983; 13: 931

21 Corbett IP, Henry JA, Angus B, Watchorn CJ, Wilkinson L, Henessy C, et al. NCL-CB11, a new monoclonal antibody recognising the internal domain of the c-erbB2 oncogen protein effective for use on formalin-fixed paraffinembedded tissue. F Pathol 1990; 161: 15-25.

22 Walker RA. Senior PV, Jones JL, Critchley DR, Varley JM. An immunohistochemical and in-situ hybridisation study of c-myc and c-erbB2 expression in primary human breast carcinomas. I Pathol 1989; 158: 97-105.

23 Going JJ, Williams ARW, Wyllie AH, Anderson TJ, Piris J Optimal preservation of p21 Ras immunoreactivity and morphology in paraffin-embedded tissue. F Pathol 1988 155: $185-90$.

24 Bartek J, Bartkova J, Vojtesek B, Staskova Z, Lukas J, Rejthar $A$, et al. Aberrant expression of the p53 oncoprotein is a common feature of a wide spectrum of human malignancies. Oncogene (in press)

25 Wasilenko WJ, Nori M, Tem M. Inhibition of epidermal growth factor receptor biosynthesis caused by the sre oncogene product, 0060v-src. Mol Cell Biol 1990; 10: 125 t

26 Polak JM, Van Noorden S. Immunocvtochemistry, practical applications in pathologv and biologv. Boston: Wright-PSG, $1983 ; 230-42$.

27 Yokota J, Yamamoto T, Miyajima N, Toyoshima K, Nomura $\mathrm{N}$, Sakamoto $\mathrm{H}$, et al. Genetic alterations of the $\mathrm{c}$-erbB2 oncogene occur frequently in tubular adenocarcinoma of stomach and are often accompanied by amplification of the stomach and are often accompanied by amplific

28 Jain S, Filipe MI, Gullick WJ, Linehan J, Morris RW. C. erbB2 proto-oncogene expression and its relationship to
survival in gastric carcinoma: an immunohistochemical study on archival material. Int $f$ (incer 1991; 48: 668-71.

29 Yoshida K, Yaui W, Ito H, Tahara E. Growth factors in progression of human esophageal and gastric carcinomas. Exp Pathol 1990; 40: 291-300. 
30 Yonemura Y, Ninomiva I, Ohoyama S, Kimura H, Yamaguchi A, Fushida $\mathrm{S}$, et al. Expression of c-erbB2 oncoprotein in A , Fushida $\mathrm{S}$, et al. Expression of c-erbB2 oncoprotein in an independent indicator of poor short-term prognosis in an independent indicator of poor short-term prognosis in

patients with gastric carcinoma. Cancer 1991; 676: 2914-8.
31 Maihle NJ, Flickinger TW, Raines MA, Sanders ML, Kung HJ. Native avain c-erbB gene expresses a secreted protein product corresponding to the ligand-binding domain of the receptor. Proc Natl Acad Sci 1991; 88: 1825-9.

32 Lane DP, Benchimol S. p53 oncogene or anti-oncogene. Genes Dev 1990; 4: 1-8.

33 Baker SJ, Markovitz S, Fearon ER, Wilson JKV, Vogelstein B. Suppression of human colorectal carcinoma cell growth by wild type p53. Science $1990 ; 249: 12-5$.

34 Mercer WE, Shields MT, Lin D, Appella E, Ullrich SJ Growth suppression induced by wild-type p 53 protein is accompanied by selective down-regulation of proliferatingaccompanied by selective down-regulation of proliferating-
cell nuclear antigen expression. Proc Natl Acad Sci 1991; 88: cell nuclear

35 Hollstein MC, Metcalf RA, Welsh JA, Montesano R, Harris CC. Frequent mutation of the p53 gene in human esophageal cancer. Prop Natl Acad Sci 1990; 87: 9958-61.

36 Baserga R. Growth regulation of the PCNA gene. $7 \mathrm{Cell} \mathrm{Sci}$ 1991; 98: 433-6.

37 Walker RA, Wilkinson N. p21 Ras protein expression in benign and malignant human breast. $\mathcal{F}$ Pathol 1988; 156 147-53.

38 Meltzer SJ, Zhou D, Weinstein WM. Tissue specific expression of c-Ha-ras in premalignant gastrintestinal mucosae. Exp Mol Pathol 1989; 51: 264-74.

39 Ravikumar TS, Barbara W, Cocchiaro C, D'Emilia J, Steel G. Ras gene activation and epidermal growth factor receptor Ras gene activation and epidermal growth factor receptor
expression in human colon cancer. $\mathcal{F}$ Surg Res $1989 ; 47: 418-$ 22 .

40 Karayiannis M, Yiagnisis M, Papdimitriou K, Spandido DA Expression of the ras oncoprotein in gastric carcinomas and adjacent mucosa. Anticancer Res 1989; 9: 1505-10.

41 Dunn TL, Seymour GJ, Gardiner RA, Strutton GM, Lavin $\mathrm{MF}$. Imunocytochemical demonstration of $\mathrm{p} 21$ ras in normal and transitional cell carcinoma of the urothelium. $\mathcal{F}$ Pathol 1988; 156: 59-65.

42 Yoshida K, Hamatani $\mathrm{K}$, Koide $\mathrm{H}$, Abe $\mathrm{Y}$, Ikeda $\mathrm{H}$, Tsuchiyama $\mathrm{H}$, et al. Analysis of ras gene expression in stomach cancer by anti-ras p21 monoclonal antibodies. Cancer Detect Prev 1988; 12: 369-76.

43 Takemura N, Yasui W, Yoshida K, Tsujino T, Nakayama H Kameda $T$, et al. pp60-src protein kinase activity in human gastric carcinomas. Int $\mathcal{f}$ Cancer 1990; 45: 847-51

44 Novikov LB, Kalinovski VP, Kniazev PG, Fedorov SN, Tlevlesov NLA. Proto-oncogene expression in human carcinomas of the stomach and the gastric mucosa of rat exposed to $\mathrm{N}$-methyl-N-nitro- $\mathrm{N}$-nitrosoguanidine-induced gastric carcinogenesis. Eksp Onkol 1989; 11: 18-21.

45 Yamamoto T, Yasui W, Ochiai A, Ito H, Abe K, Yanaihara N, et al. Immunohistochemical detection of $\mathrm{c}$-myc oncogene et al. Immunohistochemical detection of c-myc oncogene product in human gastric carcinomas: expression in tum
cells and stromal cells. $\mathcal{F}$ p $\mathcal{F}$ Cancer 1987; 78: 1169-74.

46 Yanagihara K, Seyama T, Tsumuraya M, Kamada N, Yokoro $\mathrm{K}$. Establishment and characterisation of human signet ring cell gastric carcinoma cell lines with amplification of the $\mathrm{c}-$ myc oncogene. Cancer Res 1991; 51: 381-6.

47 Ryder K, Nathans D. Induction of proto-oncogene c-jun by serum growth factors. Proc Natl Acad Sci 1988; 85: 846+7.

48 Ryseck RP, Hirai SI, Yaniv M, Bravo R. Transcriptional activation of c-jun during the $\mathrm{GO} / \mathrm{Gl}$ transition in mouse fibroblasts. Nature 1988; 334: 535-7.

49 Rodrigues NR, Rowan A, Smith MEF, Kerr IB, Bodmer WF, Gannon JV, et al. p53 mutations in colorectal cancer. Proc Natl Acad Sci USA 1990; 87: 7555-9.

50 Jankowski J, Hopwood D, Wormsley KG. Expression of epidermal growth factor, transforming growth factor alpha and their receptor in gastro-esophageal diseases; a review. Dig Dis (in press)

51 Jankowski J, Jankowski R. Epidemiology of oesophageal cancer (letter). Eur $\mathcal{F}$ Gastroenterol Hepatol 1991; 3: 955-6. 